\title{
Substantial expression of luteinizing hormone-releasing hormone (LHRH) receptor type I in human uveal melanoma
}

\author{
Andrea Treszl ${ }^{1, *}$, Zita Steiber ${ }^{2, *}$, Andrew V. Schally, ${ }^{3,4}$, Norman L Block ${ }^{3,4}$, Balazs \\ Dezso ${ }^{5}$, Gabor Olah ${ }^{1}$, Bernadett Rozsa ${ }^{1}$, Klara Fodor ${ }^{1}$, Armin Buglyo ${ }^{1}$, Janos Gardi ${ }^{6}$, \\ Andras Berta ${ }^{2}$ and Gabor Halmos ${ }^{1,3}$ \\ ${ }^{1}$ Department of Biopharmacy, University of Debrecen, Medical and Health Science Center, Debrecen, Hungary \\ 2 Department of Ophthalmology, University of Debrecen, Medical and Health Science Center, Debrecen, Hungary \\ ${ }^{3}$ Veterans Affairs Medical Center Miami, FL, South Florida VA Foundation for Research and Education, Miami, FL and \\ Department of Pathology, University of Miami, Miller School of Medicine, Miami, FL, USA \\ ${ }^{4}$ Divisions of Hematology/Oncology and Endocrinology, Department of Medicine, University of Miami, Miller School of \\ Medicine, Miami, FL, USA \\ ${ }^{5}$ Department of Pathology, University of Debrecen, Medical and Health Science Center, Debrecen, Hungary \\ ${ }^{6}$ Department of Endocrinology, University of Szeged, Faculty of Medicine, Szeged, Hungary \\ * These authors contributed equally to this work. \\ Correspondence to: Gabor Halmos, email: halmos.gabor@pharm.unideb.hu \\ Andrew V. Schally, email: Andrew.Schally@va.gov
}

Keywords: uveal melanoma, luteinizing hormone-releasing hormone (LHRH) receptor

Received: September 5, $2013 \quad$ Accepted: September 8, $2013 \quad$ Published: September 10, 2013

This is an open-access article distributed under the terms of the Creative Commons Attribution License, which permits unrestricted use, distribution, and reproduction in any medium, provided the original author and source are credited.

\section{ABSTRACT:}

Uveal melanoma is the most common primary intraocular malignancy in adults, with a very high mortality rate due to frequent liver metastases. Consequently, the therapy of uveal melanoma remains a major clinical challenge and new treatment approaches are needed. For improving diagnosis and designing a rational and effective therapy, it is essential to elucidate molecular characteristics of this malignancy. The aim of this study therefore was to evaluate as a potential therapeutic target the expression of luteinizing hormone-releasing hormone (LHRH) receptor in human uveal melanoma. The expression of LHRH ligand and LHRH receptor transcript forms was studied in 39 human uveal melanoma specimens by RT-PCR using gene specific primers. The binding charachteristics of receptors for LHRH on 10 samples were determined by ligand competition assays. The presence of LHRH receptor protein was further evaluated by immunohistochemistry. The expression of mRNA for type I LHRH receptor was detected in 18 of $39(46 \%)$ of tissue specimens. mRNA for LHRH-I ligand could be detected in 27 of $39(69 \%)$ of the samples. Seven of 10 samples investigated showed high affinity LHRH-I receptors. The specific presence of full length LHRH receptor protein was further confirmed by immunohistochemistry. A high percentage of uveal melanomas express mRNA and protein for type-I LHRH receptors. Our results support the merit of further investigation of LHRH receptors in human ophthalmological tumors. Since diverse analogs of LHRH are in clinical trials or are already used for the treatment of various cancers, these analogs could be considered for the LHRH receptor-based treatment of uveal melanoma.

\section{INTRODUCTION}

Although uveal melanoma is very rare, it is the most common primary intraocular malignancy in adults.
Its incidence in the Western world seems to be relatively stable with about 7 new cases per year per 1 million individual. About half of the patients already have metastatic disease by the time of diagnosis. The outcome 
of these is almost invariably fatal and death usually occurs within a year of the onset of systemic symptoms. [1,2] Treatment by systemic or intra-hepatic chemotherapy or partial hepatectomy only rarely prolongs the survival [3], emphasizing the need to develop more efficacious therapies. Recent progress in our understanding of the molecular processes underlying uveal melanoma should enable us to advance the diagnosis, prognosis and treatment of this malignancy.

The discovery of specific receptors for peptide hormones on cancer cells has led to the development of cytotoxic and radiolabeled hormone analogs that are useful for tumor localization and targeted therapy. Various preclinical studies have shown that chemotherapy based on cytotoxic peptide conjugates targeted to receptors on tumors can improve the effectiveness of treatment and reduce general side effects. [4]

The presence of different isoforms of Luteinizing Hormone-Releasing Hormone (LHRH) also known as Gonadotropin Hormone-Releasing Hormone has been identified in vertebrates. LHRH is the primary link between the brain and the pituitary in the regulation of gonadal function and plays a pivotal role in vertebrate reproduction. The actions of LHRH are mediated by high affinity receptors for LHRH. The discovery of LHRH has had a major impact in medicine and has led to a variety of clinical uses of LHRH analogs in oncology and gynecology. [5] Recently, it has been shown that various cancer cell lines, including cutaneous melanoma, xenografted into nude mice, can be inhibited by the targeted cytotoxic LHRH analog AN-152 (AEZS-108). [6] Since both cutaneous melanoma and uveal melanoma have the same neuroectodermal origin, but the presence of LHRH receptors has never been studied in uveal melanoma, we investigated the expression of mRNAs for LHRH-I ligand and for type I LHRH receptor in specimens of human uveal melanoma. The presence and binding characteristics of LHRH receptor protein were also examined.

\section{RESULTS}

\section{Expression of human type-I LHRH receptors in human uveal melanoma}

Our specimens of uveal melanoma tissue consisted of 11 epithelioid, 21 spindle and 7 mixed cell type tumors. The tumor thickness range was 6-12.9 $\mathrm{mm}$ according to ultrasonography. The tumor basal diameters as measured with ultrasonography, ranged from 9-19 $\mathrm{mm}$. If the tumor thickness was more than $8 \mathrm{~mm}$ and/or the largest tumor diameter was more than $13 \mathrm{~mm}$, we enucleated the eye without prior treatment. In those cases where the thickness was less than $8 \mathrm{~mm}$ or the basal diameter was less than $13 \mathrm{~mm}$, but the tumor was growing in spite of the previous transpupillary thermotherapy and/or Ruthenium-106 plaque brachytherapy, enucleation was performed. Based on our recent knowledge, type I LHRH receptor has two splice variants, but only the full length receptor is functional. Our primer set for LHRH receptor was designed to specifically amplify the mRNA of the full length receptor, but to give no signals for the splice variants. We used LHRH receptor primers encompassing the open reading frame from exon 2 to exon 3, overlapping the missing part in the above mentioned two isoforms. The predicted size of the PCR amplified cDNA for type I LHRH receptor was $241 \mathrm{bp}$. Fourty six percent of our samples expressed receptors for type I LHRH receptor (Fig. 1., Table 1.). Among epithelioid type uveal melanomas, 6 of $11(55 \%)$ were found to be positive for the expression of LHRH receptor while spindle type melanomas included 10 of $21(48 \%)$ positive samples. In the mixed cell type group (containing both epithelioid and spindle cells, with no dominant pattern), 2 of 7 (29\%) of the tumors expressed type I LHRH receptor. The presence of full length LHRH-I receptor was confirmed by immunohistochemistry and correlated well with the findings by RT-PCR (Fig. 2.). Among the specimens of RT-PCR positive uveal melanoma, the majority stained positive for LHRH receptors which could be detected in the form of red granules.

The presence of specific LHRH binding sites and characteristics of binding of $\left[{ }^{125} \mathrm{I}\right]\left[\mathrm{D}-\operatorname{Trp}^{6}\right] \mathrm{LHRH}$ to membrane receptors on human uveal melanoma tissue was determined using ligand competition assays. Of the 10 specimens examined, 7 showed LHRH receptor binding (Table 2.). Analyses of the typical displacement of radiolabeled [D-Trp $\left.{ }^{6}\right]$ LHRH by the same unlabeled peptide revealed that the one-site model provided the best fit, indicating the presence of one class of high-affinity LHRH receptors in crude membranes derived from human uveal melanoma specimens. The computerized nonlinear curvefitting and the Scatchard plot analyses of the binding data in the 7 receptor-positive tumor specimens indicated that the single class of binding sites had a mean dissociation

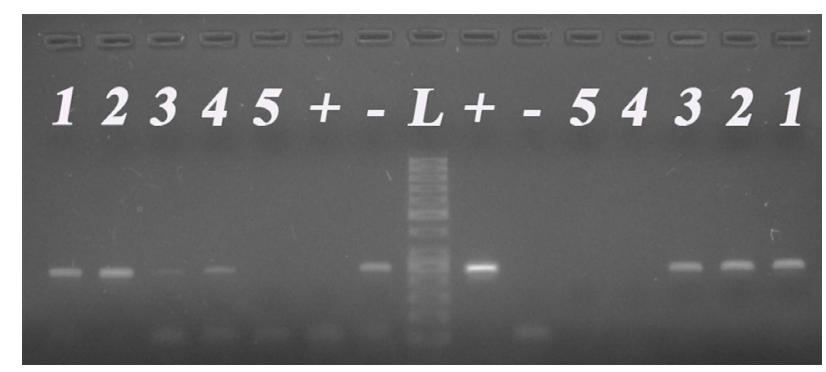

Figure 1: mRNA expression of LHRH-I (left panel) and its type I receptor (right panel) in the same tissue specimen set. L: 50 bp DNA-ladder (Fermentas); +: positive control (human pituitary); -: no template control; No. 1-5: representative human uveal melanoma tissues. 
Table 1: Clinicopathological characteristics and RT-PCR results of enucleated uveal melanoma samples

\begin{tabular}{|c|c|c|c|c|c|c|c|}
\hline Number of patient & Age at enucleation & Sex & Histology & Earlier therapy & Eye & LHRH-R & LHRH ligand \\
\hline 1. & 64 & $M$ & Spindle & - & $\mathrm{L}$ & + & + \\
\hline 2. & 39 & $\mathrm{M}$ & Epithelioid & Brachytherapy & $\mathrm{R}$ & + & - \\
\hline 3. & 70 & $M$ & Spindle & - & $\mathrm{R}$ & - & + \\
\hline 4. & 80 & $\mathrm{~F}$ & Epithelioid & - & $\mathrm{R}$ & + & - \\
\hline 5. & 47 & $\mathrm{M}$ & Epithelioid & - & $\mathrm{L}$ & - & - \\
\hline 6. & 65 & $\mathrm{M}$ & Spindle & - & $\mathrm{R}$ & + & - \\
\hline 7. & 76 & $\mathrm{M}$ & Spindle & - & $\mathrm{R}$ & + & + \\
\hline 8. & 75 & $\mathrm{~F}$ & Spindle & - & $\mathrm{L}$ & - & + \\
\hline 9. & 84 & $\mathrm{~F}$ & Spindle & Brachytherapy & $\mathrm{L}$ & + & + \\
\hline 10. & 39 & $M$ & Mixed & - & $\mathrm{R}$ & - & + \\
\hline 11. & 35 & M & Spindle & - & $\mathrm{L}$ & - & - \\
\hline 12. & 30 & $\mathrm{~F}$ & Spindle & - & $\mathrm{L}$ & + & + \\
\hline 13. & 44 & $\mathrm{~F}$ & Spinde & - & $\mathrm{L}$ & - & + \\
\hline 14. & 68 & $\mathrm{~F}$ & Spindle & - & $\mathrm{L}$ & - & + \\
\hline 15. & 76 & $\mathrm{M}$ & Spindle & - & $\mathrm{R}$ & + & + \\
\hline 16. & 79 & $\mathrm{~F}$ & Mixed & - & $\mathrm{L}$ & - & + \\
\hline 17. & 79 & $\mathrm{~F}$ & Epithelioid & - & $\mathrm{R}$ & + & + \\
\hline 18. & 67 & $M$ & Epithelioid & Brachytherapy, TTT & $\mathrm{L}$ & + & + \\
\hline 19. & 60 & $M$ & Epithelioid & Brachytherapy $(3 x)$ & $\mathrm{R}$ & + & + \\
\hline 20. & 51 & M & Spindle & - & $\mathrm{L}$ & - & + \\
\hline 21. & 66 & $M$ & Epithelioid & - & $\mathrm{R}$ & + & + \\
\hline 22. & 72 & $\mathrm{~F}$ & Epithelioid & - & $\mathrm{L}$ & - & + \\
\hline 23. & 76 & $\mathrm{M}$ & Spindle & - & $\mathrm{L}$ & + & + \\
\hline 24. & 55 & $\mathrm{M}$ & Spindle & - & $\mathrm{L}$ & - & + \\
\hline 25. & 54 & $\mathrm{M}$ & Epithelioid & - & $\mathrm{R}$ & - & + \\
\hline 26. & 75 & $\mathrm{~F}$ & Spindle & - & $\mathrm{L}$ & + & + \\
\hline 27. & 64 & $\mathrm{~F}$ & Epithelioid & - & $\mathrm{R}$ & - & + \\
\hline 28. & 61 & $M$ & Spindle & - & $\mathrm{L}$ & - & + \\
\hline 29. & 50 & $\mathrm{~F}$ & Spindle & - & $\mathrm{R}$ & + & - \\
\hline 30. & 76 & $\mathrm{M}$ & Mixed & - & $\mathrm{L}$ & + & + \\
\hline 31. & 38 & $\mathrm{M}$ & Spindle & - & $\mathrm{R}$ & - & + \\
\hline 32. & 79 & $\mathrm{~F}$ & Mixed & - & $\mathrm{R}$ & - & - \\
\hline 33. & 53 & $\mathrm{M}$ & Epithelioid & - & $\mathrm{R}$ & - & + \\
\hline 34. & 52 & $M$ & Mixed & - & $\mathrm{L}$ & - & + \\
\hline 35. & 45 & $\mathrm{M}$ & Mixed & - & $\mathrm{R}$ & + & - \\
\hline 36. & 70 & $\mathrm{M}$ & Spindle & - & $\mathrm{R}$ & + & - \\
\hline 37. & 43 & $\mathrm{M}$ & Spindle & - & $\mathrm{L}$ & - & - \\
\hline 38. & 53 & $\mathrm{M}$ & Mixed & - & $\mathrm{L}$ & - & - \\
\hline 39. & 51 & M & Spindle & Brachytherapy (3x) & $\mathrm{L}$ & - & - \\
\hline
\end{tabular}

L: left, R: right, TTT: Transpupillary Thermotherapy 
constant (Kd) of $3.69 \mathrm{nM}$ (range, 1.35 to $6.36 \mathrm{nM}$ ) with a mean maximal binding capacity (Bmax) of $384.5 \mathrm{fmol} /$ $\mathrm{mg}$ of membrane protein (range, 251.5 to $511.6 \mathrm{fmol} / \mathrm{mg}$ protein). Biochemical parameters essential to establish the identity of specific binding sites were also determined. Thus the binding of $\left.{ }^{125} \mathrm{I}\right]\left[\mathrm{D}-\mathrm{Trp}^{6}\right]$ LHRH was found to be reversible, time- and temperature-dependent, and linear with protein concentration in the human uveal melanoma specimens examined (data not shown). The specificity of LHRH binding was demonstrated by competitive binding experiments using several peptides structurally related or unrelated to LHRH (data not shown).
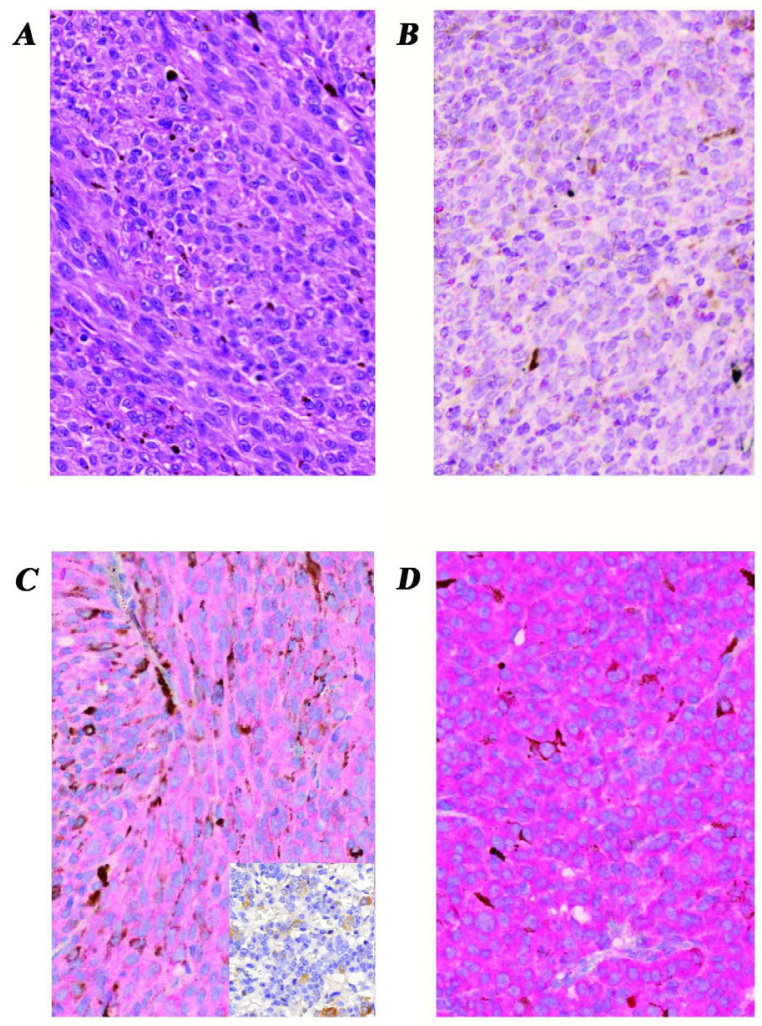

Figure 2: Expression of LHRH receptor protein in enucleated human uveal melanoma tissue samples demonstrated by immunoperoxidase staining. A, Hematoxylin-eosin stained section of a representative sample shows melanin-producing neoplastic cells with spindle and epithelioid pattern. a-d, images of representative samples immunostained for type I LHRH receptor; B, tumor sample without detectable mRNA for type I LHRH receptor also revealed no identifiable LHRH receptor protein using IHC staining; C, representative tissue section shows mild positivity for type I LHRH receptor (faint red cytoplasms of tumor cells). Insert is a negative control for the staining-specificity (see Methods); D, representative tumor sample exhibits intense expression of type I LHRH receptor in nearly $100 \%$ of tumor cells (intense red cytoplasmic staining) which correlated with the corresponding mRNA levels. Original magnifications of all images: 40x. Images B-D are immunoperoxidase stained sections with hematoxylin nuclear counterstaining.
Table 2: Expression of mRNA and binding characteristics of type I receptors for LHRH (LHRH-R) in 10 human uveal melanoma specimens.

\begin{tabular}{|l|l|l|l|}
\hline $\begin{array}{l}\text { Patient } \\
\text { No. }\end{array}$ & $\begin{array}{l}\text { LHRH-R } \\
\text { mRNA }\end{array}$ & $\begin{array}{l}\text { Bmax } \\
\text { (fmol/mg protein) }\end{array}$ & Kd (nM) \\
\hline 4. & + & 294.6 & 1.35 \\
\hline 6. & + & 398.7 & 1.37 \\
\hline 9. & + & 264.7 & 3.73 \\
\hline 11. & - & - & - \\
\hline 12. & + & 495.7 & 6.03 \\
\hline 15. & + & 251.5 & 4.81 \\
\hline 20. & - & - & - \\
\hline 24. & - & - & - \\
\hline 30. & + & 511.6 & 6.36 \\
\hline 35. & + & 474.7 & 2.18 \\
\hline
\end{tabular}

The expression of mRNA for LHRH receptors was accompanied by ligand binding in all samples examined. Three of 10 tumor specimens did not exhibit mRNA expression for type I LHRH receptors, or show ligand binding; conversely, all receptor-positive specimens expressed a detectable amount of the receptor gene (Table 2.). There was no evident correlation between receptor binding characteristics or mRNA expression and clinical and pathological findings.

\section{Expression of mRNA for human type I LHRH in human uveal melanoma}

In addition to the expression of type-I LHRH receptor, we also studied the presence of LHRH ligand in our uveal melanoma samples. The majority of uveal melanomas (27 of 39, 69\%) showed marked expression of mRNA for LHRH-I ligand (Table 1.). The expected size of the PCR product of $245 \mathrm{bp}$ could be detected in 8 of $11(73 \%)$ of epithelioid and 15 of $21(71 \%)$ of spindle type tumors. In the mixed tumor type, 4 of $7(57 \%)$ expressed LHRH-I (Fig. 1.). In 12 tumors (31\%), both LHRH-I ligand and receptor were expressed. In 6 samples, only type I LHRH receptors were present, while in 15 melanomas only LHRH-I ligand was present (Tabel 1.).

Statistical analysis showed an association between age and LHRH receptor mRNA and ligand co-expression $(\mathrm{p}=0.0407)$ : a 10 -year increase of age meant an estimated $87 \%$ increase in the odds of co-expression $(\mathrm{OR}=1.867$, $95 \%$ CI 1.027 to 3.393 ). Otherwise, there were no correlations between LHRH-I ligand or receptor mRNA expression and tumor subtype or clinical parameters. The clinicopathological characteristics of patients with uveal melanoma and the result of mRNA expression analysis are summarized in Table 1. 


\section{DISCUSSION}

Patients with uveal melanoma face a dismal prognosis as eventually about $45 \%$ of them die of metastasis, regardless of the fact that the tumor is most often diagnosed and locally cured before any signs of clinical disseminated disease appear. [7] This gave rise to the theory that micrometastases are already present early in the disease process, but remain dormant for years before a clinically detectable macrometastasis develops. [8] Most small and medium-sized uveal melanomas are currently managed by different forms of radiotherapy and local resection. However, it remains unclear what effect this treatment has on patient survival. Systemic treatment options for uveal melanoma are very limited. Adjuvant systemic therapy is mainly used in patients at high-risk of metastasis or in patients who have already developed metastasis, but the response rates to classical chemotherapeutic agents remain as low as 7\%-25\%. [9] Despite the improvements in diagnosis and therapy of primary uveal melanoma in the last 20-30 years, there has been no significant decrease in metastasis-related deaths. $[10,11]$ Thus, the development of new therapeutic modalities is mandated.

The presence of receptors for LHRH in various cancers and cancer cell lines originating from organs other than those of the reproductive system has been demonstrated by several authors. [6,12-15] It was suggested that the signal-transduction mechanisms mediated by type I of LHRH receptor are different in the pituitary and in cancer cells. $[16,17]$ It appears that in cancer cells LHRH analogs interfere with mitogenic signal transduction of growth-factor receptors and related oncogene products associated with activities of tyrosine kinases. [17,18] It has been shown that cutaneous melanomas also express receptors for LHRH. [6,13] The treatment of melanoma cells by agonists of LHRH or cytotoxic analogs of LHRH significantly inhibits cell proliferation. $[6,13]$ As uveal melanoma and melanoma of the skin are both of neural crest origin and share certain genetic characteristics, we analyzed the expression of LHRH receptors in uveal melanoma by RT-PCR, ligand competition assay and immunohistochemistry. As only the full length type I LHRH receptor is functional, our primer set was designed to selectively amplify receptor mRNA encoding the full length type I LHRH receptor but not its known splice variants. The antibody used for immunohistochemistry was also chosen to detect full length protein. In our present study, we found that $47 \%$ of our samples expressed type I receptors for LHRH. Furthermore, using ligand competition assay we examined the binding of $\left[{ }^{125} \mathrm{I}\right]\left[\mathrm{D}-\operatorname{Trp}^{6}\right] \mathrm{LHRH}$ to membrane preparations of 10 uveal melanoma specimens. We found that $70 \%$ of the human uveal melanoma samples investigated possessed specific type I LHRH receptors with a mean $\mathrm{Kd}$ of $3.69 \mathrm{nM}$ and with a mean Bmax of
$384.5 \mathrm{fmol} / \mathrm{mg}$ membrane protein. It is also important to note that all receptor-positive specimens expressed a detectable amount of the receptor gene. The receptor protein encoded by mRNA for type I LHRH receptors was also demonstrated by immunohistochemistry in tumor specimens.

The high incidence of positivity for type I LHRH receptor in uveal melanoma suggests that this tumor type might be a good candidate for therapy with LHRH analogs including the targeted cytotoxic peptide, AN-152 (AEZS108). AN-152 is already in phase III clinical trials in women with endometrial and ovarian cancers [18-20] and in phase I/II trials in men with castration resistant prostate cancer [21, Liu S, Schally AV, Dorff TB, Tsao-Wei DD, Groshen SG, Xiong S, Hawes D, Quinn DI, Tai YC, Block NL, Engel J, Pinski JK. A phase I/II trial of AN152, a targeted cytotoxic LHRH analog, in castration- and taxane-resistant prostate cancer. ASCO Annual Meeting June 3-7, 2011, Chicago, Abstract \#74003] and patients with urothelial carcinoma [Fernandez GL, Schally AV, Koru-Sengul T, Merchan JR, Flores AM, Jorda M, Datar R, Benedetto PW, Singal R, Block NL, Engel J. A phase I/II trial of AEZS-108 in locally advanced unresectable or metastatic luteinizing hormone-releasing hormone (LHRH) positive urothelial carcinoma (UC) patients who failed platinum based chemotherapy. ASCO Annual Meeting June 3-7, 2011 Chicago, Abstract \# 83230]. Targeted therapy with cytotoxic peptide analogs consisting of a peptide molecule conjugated to a cytotoxic moiety such as doxorubicin, should be more effective and less toxic than conventional systemic chemotherapy [20,22]. Their only side effect appears to be myelosuppression caused by the occasional chemical cleavage of the cytotoxic radical doxorubicin. [4,5,18-20,22] The substantial expression of LHRH-I ligand (69\%) and frequent co-expression of its receptor (31\%) in our sample set may be indicative of the presence of an autocrine/ paracrine regulatory system based on LHRH in uveal melanoma. The regulation of several proteins associated with cell proliferation and cell motility is mediated by type I LHRH receptor/LHRH-I system, suggesting their important role in metastasis formation. [23] However, the role of this high expression of LHRH found by us is not clear.

To the best of our knowledge, our findings represent the first identification of LHRH and its receptors in human uveal melanoma. Since the therapy for this malignancy is not adequate, our work may help to identify specific molecular targets for the prevention of metastasis or further proliferation of already disseminated metastases. Our findings that a high percentage of human uveal melanoma specimens express receptors for LHRH support the view that targeted cytotoxic LHRH analogs such as AN-152 could be used for an effective treatment of uveal melanoma. 


\section{METHODS}

\section{Patients and Tissue Samples}

Human uveal melanoma specimens were obtained from 39 patients, 30-84 years of age at the time of enucleation, at the Department of Ophthalmology, University of Debrecen, Hungary. Normal pituitary samples (anterior lobe) were collected at autopsy at the Department of Pathology, University of Debrecen and were used as positive controls. After surgical removal, selected portions of the melanoma tissues were flash frozen and stored at $-70^{\circ} \mathrm{C}$. Histopathological examination of each specimen was undertaken to confirm the diagnosis. The local Institutional Ethics Committee approved the collection and use of these specimens for the current study and informed consent was obtained from these patients.

\section{RNA isolation, Reverse transcription and RT- PCR}

Total RNA was isolated using AllPrep DNA/ RNA/Protein Mini kit according to the manufacturer's instructions (Qiagen, Hilden, Germany). Two hundred fifty nanograms of RNA from each sample were reverse transcribed into cDNA by QuantiTect Reverse Transcription kit (Qiagen) in a final volume of $20 \mu \mathrm{l}$. Two primer sets were designed to evaluate the expression of type I LHRH receptors (sense: 5'-GGTGGCATCAAGCATTTTAT-3', antisense: 5'ACATAGTAGGGAGTCCAGCAGACA-3') and LHRH ligand (sense: 5'-GGCCTTATTCTACTGACTTGG-3', antisense: 5'-TCTTCTGCCCAGTTTCCTCT-3'). As internal control, $\beta$-actin housekeeping gene (sense: 5'-GGCATCCTCACCCTGAAGTA-3', antisense 5'-GGGGTGTTGAAGGTCTCAAA-3') was used. In all PCR reactions, $1 \mu 1$ of cDNA was amplified in a 25 $\mu 1$ solution containing $1.5 \mathrm{mM} \mathrm{MgCl} 2,1 \mathrm{x}$ PCR buffer (Fermentas $\mathrm{GmbH}$, St. Leon-Rot, Germany), $0.3 \mathrm{mM}$ of each deoxynucleotide (Promega, Madison, WI), 1 unit of TrueStart HotStart DNA polymerase (Fermentas) and 0.25 $\mu \mathrm{M}$ of each primer. Samples were denatured for $3 \mathrm{~min}$ at $95^{\circ} \mathrm{C}$, then subjected to 40 cycles at $95^{\circ} \mathrm{C}$ for $45 \mathrm{~s}, 59^{\circ} \mathrm{C}$ for $30 \mathrm{~s}$, then $72^{\circ} \mathrm{C}$ for $1.5 \mathrm{~min}$ with a final extension at $72^{\circ} \mathrm{C}$ for $10 \mathrm{~min}$. Ten $\mu \mathrm{l}$ of each amplification reaction was then electrophoretically separated on $1.5 \%$ agarose gel, stained with ethidium bromide, and visualized under UV light.

\section{Preparation of membranes and radioligand binding studies}

Preparation of membranes for receptor studies was performed as described previously. [24] Briefly, the samples were thawed, cleaned, and then homogenized in $50 \mathrm{mM}$ Tris- $\mathrm{HCl}$ buffer ( $\mathrm{pH}$ 7.4), supplemented with protease inhibitors $(0.25 \mathrm{mM}$ Phenylmethylsulfonyl Fluoride, $0.4 \%(\mathrm{v} / \mathrm{v})$ Aprotinin and $2 \mu \mathrm{g} / \mathrm{ml}$ Pepstatin A) using an Ultra-Turrax tissue homogenizer (IKA Works, Wilmington, NC) on ice. The homogenate was centrifuged at $500 \mathrm{x} \mathrm{g}$ for 10 minutes at $4{ }^{\circ} \mathrm{C}$ to remove nuclear debris and lipid layer. The supernatant containing the crude membrane fraction was ultracentrifuged (Beckman L8-80 M) twice at 70,000x g for 50 minutes at $4{ }^{\circ} \mathrm{C}$ after resuspending in fresh buffer. The final pellet was resuspended in homogenization buffer and stored at -80 ${ }^{\circ} \mathrm{C}$ until assayed. Protein concentration was determined by the method of Bradford using a Bio-Rad protein assay kit (Bio-Rad Laboratories, Hercules, CA).

Radio-iodinated derivatives of [D-Trp $]$ LHRH were prepared by the chloramine- $\mathrm{T}$ method and purified by reverse-phase HPLC in our laboratory. [24] LHRH receptor binding assays were carried out as reported [24] using in vitro ligand competition assays based on binding of $\left.{ }^{125} \mathrm{I}\right]\left[\mathrm{D}-\mathrm{Trp}^{6}\right] \mathrm{LHRH}$ as radioligand to uveal melanoma membrane fractions. This radioligand has been wellcharacterized previously and shows high-affinity binding to human and rat pituitaries as well as human breast, prostate, and other cancers. [4-6,22,24] In brief, membrane homogenates containing 50-160 $\mu \mathrm{g}$ protein were incubated in duplicate or triplicate with $60-80,000 \mathrm{cpm}\left[{ }^{125} \mathrm{I}\right]\left[\mathrm{D}-\operatorname{Trp}^{6}\right]$ LHRH and increasing concentrations $\left(10^{-12}-10^{-6} \mathrm{M}\right)$ of nonradioactive peptides as competitors in a total volume of $150 \mu \mathrm{l}$ of binding buffer. At the end of the incubation, $125 \mu \mathrm{l}$ aliquots of suspension were transferred onto the top of $1 \mathrm{ml}$ of ice-cold binding buffer containing 1.5\% bovine serum albumin in siliconized polypropylene microcentrifuge tubes (Sigma-Aldrich $\mathrm{GmbH}$, Munich, Germany). The tubes were then centrifuged at $12,000 \mathrm{x} g$ for 3 minutes at $4{ }^{\circ} \mathrm{C}$ (Beckman J2-21M). Supernatants were aspirated and the bottoms of the tubes containing the pellet were cut off and counted in a gamma counter (Micromedic System, Huntsville, AL). Preliminary experiments were performed with membrane protein concentrations ranging from $20-250 \mu \mathrm{g} /$ tube in order to determine the minimal amount of protein required to assess specific binding at a satisfactory level. Our work showed that accurate results can be obtained over a range of 40-180 $\mu \mathrm{g}$ of membrane protein in an incubation volume of $150 \mu$ l. 


\section{Immunohistochemistry (IHC)}

Formalin-fixed paraffin-embedded tissue samples from enucleation were immunostained as described earlier. [24] Briefly, following antigen-retrieving $(\mathrm{pH}$ : 6.0) and endogenous peroxidase-block, $3 \mu \mathrm{m}$ thick sections were incubated with monoclonal antibody to LHRH-RI (NCL-GnRHR A9E4; Novocastra Laboratories Ltd., UK) at room temperature for 1 hour. After rinsing 3 times in phosphate-buffered saline (PBS; pH:7.4, 5 mins each), sections were treated with anti-mouse IgG (Fab)2coupled to horse-radish-peroxidase (HRP) of EnVision+HRP detection kit using amino-ethyl-carbasol (AEC; red; Vector Labs, UK) peroxidase substrate according to the manufacturer's instructions. The use of red chromogenic substrate avoided the color-interference between the brown melanin pigments of melanomas and the positive staining of IHC. Human pituitary glands (anterior lobe) obtained from autopsy were used as positive controls. Negative controls in which primary antibody was replaced by normal serum were also included for each IHC-run.

\section{Statistical analysis}

Variables were described using standard statistics. Association between categorical variables were assessed using Fisher's exact tests, while those between continuous explanatory variables and binary outcomes were assessed using logistic regression, and expressed in terms of odds ratio (OR) and $95 \%$ confidence intervals $(\mathrm{CI})$.

\section{ACKNOWLEDGEMENT}

This work was supported by Zoltan Magyary Postdoctoral Fellowship supported by EEA Grants and Norway Grants (A.T.), Hungarian Scientific Research Fund (OTKA) K 81596 (G.H.) and TAMOP 4.2.2.A$11 / 1 / \mathrm{KONV}-2012-0025$ project (G.H.). The project is co-financed by the European Union and the European Social Fund. No potential conflict of interest exists for the authors.

\section{REFERENCES}

1. Damato B. Does ocular treatment of uveal melanoma influence survival? Br J Cancer. 2010;103:285-290.

2. Eskelin S, Pyrhönen S, Hahka-Kemppinen M, Tuomaala S, Kivelä T. A prognostic model and staging for metastatic uveal melanoma. Cancer. 2003;97:465-475.

3. Augsburger JJ, Correa ZM, Shaikh AH. Effectiveness of treatments for metastatic uveal melanoma. Am J Ophthalmol. 2009;148:119-127.

4. Schally AV, Nagy A. Chemotherapy targeted to cancers through tumoral hormone receptors. Trends Endocrinol
Metab. 2004;15:300-310.

5. Schally AV, Engel J. Drug insight: clinical use of agonists and antagonists of Luteinizing hormone-releasing hormone. Nat Clin Pract Endocrinol Metab. 2007;3:157-167.

6. Keller G, Schally AV, Gaiser T, Nagy A, Baker B, Westphal G, Halmos G, Engel JB. Human malignant melanomas express receptors for luteinizing hormone releasing hormone allowing targeted therapy with cytotoxic luteinizing hormone releasing hormone analogue. Cancer Res. 2005;65:5857-5863.

7. Ossowski L, Aguirre-Ghiso JA. Dormancy of metastatic melanoma. Pigment Cell Melanoma Res. 2010;23:41-56.

8. Eskelin S, Pyrhönen S, Summanen P, Hahka-Kemppinen M, Kivelä T. Tumor doubling times in metastatic malignant melanoma of the uvea: tumor progression before and after treatment. Ophthalmology. 2000;107:1443-1449.

9. Bedikian AY. Metastatic uveal melanoma therapy: current options. Int Ophthalmol Clin. 2006;46:151-166.

10. Harbour JW. Molecular prognostic testing and individualized patient care in uveal melanoma. Am J Ophthalmol. 2009;148:823-829.

11. Singh AD, Topham A. Survival rates with uveal melanoma in the United States: 1973-1997. Ophthalmology. 2003;110:962-965.

12. Fekete M, Zalatnai A, Comaru-Schally AM, Schally AV. Membrane receptors for peptides in experimental and human pancreatic cancers. Pancreas. 1989;4:521-528.

13. Moretti RM, Montagnani Marelli M, van Groeninghen JC, Limonta P. Locally expressed Luteinizing hormonereleasing hormone (LHRH) receptors mediate the oncostatic and antimetastatic activity of LHRH agonists on melanoma cells. J Clin Endocrinol Metab. 2002;87:3791-3797.

14. Keller G, Schally AV, Gaiser T, Nagy A, Baker B, Halmos $\mathrm{G}$, Engel JB. Receptors for luteinizing hormone releasing hormone (LHRH) expressed in human non-Hodgkin's lymphomas can be targeted for therapy with the cytotoxic LHRH analogue AN-207. Eur J Cancer. 2005;41:21962202.

15. Szepeshazi K, Schally AV, Halmos G. LH-RH receptors in human colorectal cancers: unexpected molecular targets for experimental therapy. Int J Oncol. 2007;30:1485-1492.

16. Moretti MR, Marelli MM, Dondi D, Poletti A, Martini L, Motta M, Limonta P. Luteinizing hormone-releasing hormone agonists interfere with the stimulator action of epidermal growth factor in human prostatic cancer cell lines, LNCaP and DU 145. J Clin Endocrinol Metab. 1996;81:393-337.

17. Emons G, Ortmann O, Schulz KD, Schally AV. Growthinhibitory actions of analogs of Luteinizing Hormone Releasing Hormone on tumor cells. Trends Endocrinol Metab. 1997;8:355-362.

18. Emons G, Sindermann H, Engel J, Schally AV, Gründker C. Luteinizing hormone-releasing hormone receptortargeted chemotherapy using AN-152. Neuroendocrinology. 
2009;90:15-18.

19. Emons G, Kaufmann M, Gorchev G, Tsekova V, Gründker C, Günthert AR, Hanker LC, Velikova M, Sindermann H, Engel J, Schally AV. Dose escalation and pharmacokinetic study of AEZS-108 (AN-152), an LHRH agonist linked to doxorubicin, in women with LHRH receptor-positive tumors. Gynecol Oncol. 2010;119:457-461.

20. Schally AV, Engel JB, Emons G, Block NL, Pinski J. Use of analogs of peptide hormones conjugated to cytotoxic radicals for chemotherapy targeted to receptors on tumors. Curr Drug Deliv. 2011;8:11-25.

21. Liu SV, Schally AV, Hawes D, Xiong S, Fazli L, Gleave M, Cai J, Groshen S, Brands F, Engel J, Pinski J. Expression of receptors for Luteinizing hormone-releasing hormone (LH-RH) in prostate cancers following therapy with LHRH agonists. Clin Cancer Res. 2010;16:4675-4680.

22. Schally AV, Halmos G. Targeting to Peptide Receptors. In: Kratz Felix, Senter Peter, Steinhagen Henning. Drug Delivery in Oncology: From Basic Research to Cancer Therapy. Weinheim: Wiley-VCH, 2012. pp. 1219-1262.

23. Aguilar-Rojas A, Huerta-Reyes M. Human gonadotropinreleasing hormone receptor-activated cellular functions and signaling pathways in extra-pituitary tissues and cancer cells. Oncol Rep. 2009;22:981-990.

24. Rozsa B, Nadji M, Schally AV, Dezso B, Flasko T, Toth G, Mile M, Block NL, Halmos G. Receptors for Luteinizing hormone-releasing hormone (LHRH) in benign prostatic hyperplasia (BPH) as potential molecular targets for therapy with LHRH antagonist cetrorelix. Prostate. 2011;71:445452. 